\title{
The Sherman Act and the Harvester Case
}

W

ITH the enactment of the anti-trust program of the administration, ${ }^{1}$ it is evident that this country has passed into a stage of regulation and control of large industrial corporations. ${ }^{2}$ The new legislation is, however, avowedly designed, not to repeal, but to supplement the present statutes dealing with combinations. ${ }^{3}$ For this reason the attention of those who desire to interpret and apply the corporation laws passed at the present session of Congress must first be directed to the scope of the Sherman Act as it is now construed by the courts.

At the present time, therefore, the treatment of the Sherman Act by the court in the case of United States v. International Harvester Company, ${ }^{4}$ is of more than usual interest. This action was brought by the government to dissolve the International Harvester Company as an illegal combination in undue restraint of trade, and hence illegal under the Anti-Trust Act. It was held that the defendant company was such a combination in restraint of trade and it was ordered that the property of the company be divided among distinct independent corporations. The case was tried before Cịrcuit Judges Sanborn, Hook and Smith. Judge Sanborn

1 The administration trust legislation as finally passed consisted of "An Act to create a Federal Trade Commission" approved on September 26, 1914, and of "An Act to Supplement Existing Laws against Restraints and Monopolies, and for other Purposes" (The Clayton Act) approved on October 15, 1914.

2 The Federal Trade Commission has power to compel corporations to file with the Commission annual or special reports in such form as may be prescribed by the Commission, ( $\$ 6$ (b) Fed. Trade Comm. Act). Power is also given to the Commission to suppress "unfair methods of competition .... if it shall appear to the Commission that a proceeding by it in respect thereof would be to the interest of the public." ( $\$ 5$ Fed. Trade Comm. Act.)

${ }^{3}$ See Report of Senate Committee on Judiciary reporting Clayton Bill as amended. Here it was said: "It is not proposed by the bill or amendments thereto to alter, amend or change in any respect the original Anti-Trust Act of July, 1890 . The purpose is only to supplement that act and the other anti-trust acts referred to in section one of the bill."

4(August 12, 1914), 214 Fed. 987. 
dissented from the main opinion, which was written by Judge Smith and concurred in by Judge Hook. The court was well acquainted with actions arising under the Sherman Act, since Judges Sanborn and Hook had sat in the cases of United States v. Union Pacific Railroad Company ${ }^{5}$ and United States v. Standard Oil Company, ${ }^{6}$ and the former concurred in the Northern Securities decision. ${ }^{7}$

The significance of the case lies in the fact that the Harvester Company was at once a large corporation and a corporation which dealt fairly with its business rivals. In its fair methods of competition, the Harvester Company differed from the Standard Oil Company, the Tobacco Company and the other large industrial companies theretofore held illegal under the Sherman Act. Organized in 1902, with a capitalization of $\$ 120,000,000$, the result of a combination of five large companies, it produced eighty to eighty-five per cent of the binders, mowers, reapers and rakes sold in the United States. That the corporation did not use its natural power to oppress its competitors and create a monopoly is shown by the opinions rendered in the action.

The opinion of the court, rendered by Judge Smith, reads in part :

"While the evidence shows some instances of attempted oppression of the American trade by the International and the America Companies, such cases are sporadic, and in general their treatment of their smaller competitors has been fair and just."

Judge Hook, writing a short concurring opinion, declares:

"It is but just, however, to say and to make it plain that in the main the business conduct of the company towards its competitors and the public has been honorable, clean, and fair."

In his dissenting opinion, Judge Sanborn says:

"The weight of the evidence of the officers and agents of their competitors, who came in large numbers to testify, and of all the witnesses upon the subject, is so overwhelming that

5 (1911), 188 Fed. 102, on appeal (1912), 226 U. S. 61, 57 L. Ed. 97, 33 Sup. Ct. Rep. 1.

6 (1909), 173 Fed. 177, on appeal (1911), 221 U. S. 1, 55 L. Ed. 619, 31 Sup. Ct. Rep. 502 .

7 U. S. v. Northern Securities Co. (1903), 120 Fed. 721, on appeal, Northern Securities Co. v. U. S. (1904), 193 U. S. 197, 48 L. Ed. 679, 24 Sup. Ct. Rep. 436.

8214 Fed. 987 , at p. 993.

9214 Fed. 987, at p. 1002 . 
the general conduct and the almost universal practice of the defendants and their agents was and is free from all methods and acts either unlawful, unfair, or oppressive towards their competitors, that it has left no doubt that the consistent and persistent purpose, policy, rule of action, and practice of the defendants has been and is to avoid and prevent all acts and methods unfair, unjust, or oppressive towards their competitors." 10

Thus the question came before the court for the first time: Is a consolidation of competing industrial companies into one large corporation, resulting in the acquisition by that corporation of a large proportion of a certain field of business, necessarily invalid? The answer of the court in the Harvester case is in the affirmative when there is not sufficient excuse shown for the consolidation. And this is irrespective of the conduct of the corporation after the combination has taken place.

To realize the meaning of the Harvester Company decision it is necessary to examine briefly the recent cases arising under the Sherman Act. The first suit in which the Sherman Act was held to forbid the acquisition of competitive railway lines or industries by a single corporation was the Northern Securities case. ${ }^{11}$ This case was decided by the lower court in 1903, and by the United States Supreme Court in I904. ${ }^{12}$ Prior to that time there had been but one suit brought under the Sherman Act against a large corporation in which the fact of combination into corporate form was alleged to be illegal. That was the case of United States v. E. C. Knight Company, ${ }^{13}$ which action was lost by the government as the court held that the corporation in question was not engaged in interstate commerce.

From 1890 to 1903 , therefore, the Sherman Act was applied solely to combinations of men or of corporations which remained imdependent of each other after the combinations were entered into. The agreements of manufacturers to pool their products and keep prices up, the combinations of railroads to share traffic and act in unison in ratemaking-the kind of agreements which, when in unreasonable restraint of trade, were illegal at common law-these were the agreements which were held illegal under the Sherman Act by the courts prior to 1903 .

10214 Fed. 987 , at p. 1008.

11 (1903), 193 U. S. 197, 48 L. Ed. 679, 24 Sup. Ct. Rep. 436.

12 U. S. v. Northern Securities Co. (1903), 120 Fed. 721, on appeal (1904), 193 U. S. 197, 48 L. Ed. 679, 24 Sup. Ct. Rep. 436.

13 (1894), 156 U. S. 1, 39 I. Ed. 325, 15 Sup. Ct. Rep. 249. 
In the Securities case, three judges of the United States Supreme Court concurred with Mr. Justice Holmes in his opinion that the contracts in restraint of trade forbidden by the Sherman Act were "contracts with strangers to the contractor's business, and the trade restrained was the contractor's own". But the bare majority of the court held that the Northern Securities Company, a company holding the stocks of two competing railroad companies, was in itself a combination in restraint of trade under the Sherman Anti-Trust Act. With the Securities case, therefore, begins the history of the application of the Sherman Act to large corporations.

Between the date of the delivery of the Northern Securities decision and the handing down of the opinion in Standard Oil Company v. United States, ${ }^{14}$ in I9II, the legality of nearly every large business house doing an interstate trade in America was open to doubt. In the Trans-Missouri case, ${ }^{15}$ the Supreme Court had declared that all combinations which restrained trade, unreasonably or reasonably, were illegal. Now inasmuch as any consolidation of competing concerns into a corporation ended competition between them, under the broad theory of the law promulgated in the Securities case, all corporations made up of former competitors were illegal. It was not surprising that Mr. Justice Holmes spoke of the majority opinion in the Securities case as "an interpretation of the law which in my opinion would make eternal the bellum omnium contra omnes and disintegrate society so far as it could into individual atoms. If that were its intent I should regard calling such a law a regulation of commerce as a mere pretense. It would be an attempt to reconstruct society." ${ }^{\prime 6}$

Judge Lacombe, rendering the opinion of the lower court in the Tobacco case, in I908, made perfectly clear the seriousness of the broad holding in the Securities case. He said of the construction of the Sherman Act by the Supreme Court:

"The act as above construed prohibits every contract or combination in restraint of competition. Size is not made the test: Two individuals who have been driving rival express wagons between villages in two contiguous states, who enter into a combination to join forces and operate a single line, restrain an existing competition and it would seem to make

14221 U. S. 1, 55 L. Ed. 619, 31 Sup. Ct. Rep. 502.

15.U. S. v. Trans-Missouri Freight Assn. (1896), 166 U. S. 290, 41 I. Ed. 1007, 17 Sup. Ct. Rep. 540.

${ }_{16}$ U. S. v. Northern Securities Co. (1904), 193 U. S. 197, at p. 411. 
little difference whether they make such combination more effective by forming a partnership or not.",17

When the Standard Oil and Tobacco cases came up on appeal the Justices of the Supreme Court had a choice-they could definitely hold that all combinations which restrained competition were illegal, in which event the Sherman Act would be so broad as to be practically unenforcible against all offenders and would remain a weapon to be used by the executive branch of the government at its caprice; or they could overthrow their ruling in the Trans-Missouri case and hold that combinations forbidden were combinations unduly in restraint of trade. The Supreme Court chose the latter course.

In the Standard Oil case the court held that the Sherman Act should be construed in the light of reason and, as so construed, it prohibited only contracts and combinations which amounted to an unreasonable or undue restraint of trade in interstate commerce. Of the effect of mere consolidation of the industry the court said:

"Because the unification of power and control over petroleum and its products which was the inevitable result of the combining in the New Jersey corporation by the increase of its stock and the transfer to it of the stocks of so many other corporations, aggregating so vast a capital, gives rise, in and of itself, in the absence of countervailing circumstances, to say the least, to the prima facie presumption of intent and purpose to maintain the dominancy over the oil industry, not as a result of normal methods of industrial development, but by new means of combination which were resorted to in order that greater power might be added than would otherwise have arisen had normal methods been followed, the whole with the purpose of excluding others from the trade and thus centralizing in the combination a perpetual control of the movements of petroleum and its products in the channels of interstate commerce." 18

This presumption was made conclusive by the proof developed of the specific acts of the Standard Oil Company showing its determination to drive its rivals out of business. So in the proceeding against the American Tobacco Company, the history of the combination was replete with acts "demonstrative of the existence from the beginning of a purpose to acquire dominion and control of the tobacco trade, not by the mere exertion of the ordinary right to contract and to trade, but by methods devised 
in order to monopolize the trade by driving competitors out of business, which were ruthlessly carried out upon the assumption that to work upon the fears or play upon the cupidity of competitors would make success possible". ${ }^{19}$

By the decisions in the Standard Oil and Tobacco cases, a great development was made in the law affecting combinations. All consolidations of competing plants were not illegal but such consolidations, if extended, made a prima facie case of illegality. And proof of the rough, harsh methods which at one time characterized the efforts of large companies to secure the business of their smaller rivals made the illegality conclusive. Combinations were henceforth to be adjudged in the light of reason and only combinations in undue restraint of trade to be forbidden. But this very method of judging the legality of corporations naturally left great uncertainty in the busmess world. Necessarily the standard of reasonableness was one on which men would differ. Few corporations could qualify as having indulged in all the practices condemned in the Standard Oil and Tobacco cases. As a result, a great number of large industrial corporations did not know in I9Ir, and do not know now, whether they are legal or illegal combinations of capital.

There are numerous precedents involving the validity of contracts between strangers which restrain trade. This subject has been before the common law courts for over a century. But for cases dealing with the validity of corporate consolidations, the person seeking enlightenment must look almost entirely to decisions arising under the Sherman Anti-Trust Act. And as the interpretation of the Sherman Act was radically changed by the court in the Standard Oil and Tobacco cases, it must be those cases and the subsequent decisions which must be examined.

Unfortunately since the Standard Oil and Tobacco cases, no decisions involving the validity of any large consolidations of industries in corporate form have been handed down by the Supreme Court. In recent cases that court has passed upon the legality of railroad combinations or of combinations of sundry independent dealers through agreement. Cases involving railroad combimations are most applicable to questions as to the validity of industrial combinations, when the offense complained of is the

${ }^{19}$ U. S. v. American Tobacco Co. (1910), 221 U. S. 106, at p. 181. 
absorption of competing routes into a single corporation and not a mere agreement between independent carriers.

In the case of United States v. Union Pacific Railroad Company, ${ }^{20}$ the Supreme Court handed down its most significant decisions viewed from the standpoint of industrial consolidation. Here the government tested the legality of the acquisition in Igor of a controlling interest in the Southern Pacific Company by the Union Pacific Railway Company. It was shown that the coinpetitive business prior to Igor was under four per cent of the gross business of each road, although the receipts from that traffic ran into many millions. The lower court held that the combination was a legal one. ${ }^{21}$ Judge Hook, however, filed a vigorous dissent. On appeal, the Supreme Court held that the acquisition of the stock was illegal and in violation of the Sherman Act.

It is to be hoped that the rather strict principles of this case are not to be applied to industrial corporations. The case closely follows the holding of the Northern Securities case. That railroad companies are in a class by themselves was brought out by $\mathrm{Mr}$. Justice Brewer in his concurring opinion in the Securities case when he said:

"It must also be remembered that under present conditions a single railroad is, if not a legal, largely a practical monopoly, and the arrangement by which the control of these two competing roads was merged in a single corporation broadens and extends such monopoly." 22

If the decision simply affirms the Northern Securities case under the new view of the Sherman Act and means that combinations between competing lines of railroads are unlawful, the case has little bearing on industrial combinations. Should the case be construed as authority for holding that any consolidation between competing corporations, where the competitive business was so small as four per cent of the gross earnings of the companies, is illegal, the state of the law as applied to industrial corporations immediately becomes chaotic.

The Reading case ${ }^{23}$ and the St. Louis Terminal case ${ }^{24}$ throw

20 (1912), 226 U. S. 61, 57 I. Ed. 97, 33 Sup. Ct. Rep. 1.

21 U. S. v. Union Pacific R. R. Co. (1911), 188 Fed. 102.

22 U. S. v. Northern Securities Co. (1904), 193 U. S. 197, at p. 363

${ }^{23}$ U. S v. Reading Co. (1912), 226 U. S. 324, 57 I. Ed. 243, 33 Sup. Ct. Rep. 90.

24 U. S. v. Terminal R. R. Assn. (1912), 224 U. S. 383, 56 L. Ed. 857, 32 Sup. Ct. Rep. 550. 
little light upon the question of the legality of combinations of competing businesses in one corporation. Both cases involved agreements and combinations between competing but independent railroads. In the Reading case the railroads held proportionate interests in the stock of a colliery company, which controlled a great coal tonnage. This stock had been bought to head off the construction of an independent railroad from the coal fields to tide water. The railroads had also built up a system of contracts with the mining companies which gave the former a substantial control over coal prices. Both the common stock ownership and the system of contracts were held illegal. In the Terminal case control of the terminal facilities by a minority of the railroads compelled to use it was held a combination in restraint of trade.

The Bath Tub Trust case ${ }^{25}$ and the Pacific and Arctic Railway and Navigation case ${ }^{26}$ do not touch upon the legality of corporate consolidations. Combinations between independent dealers or carriers have been dwelt on at length by the common law judges and there is furthermore no compelling reason to believe that such combinations as those held illegal in the Addyston Pipe, ${ }^{27}$ Montague $^{28}$ Trans-Missouri ${ }^{28}$ cases would not be held illegal today. ${ }^{30}$

There have been three cases since the Tobacco case decision in which the validity of large industrial corporations under the Sher-

${ }^{25}$ Standard Sanitary Mfg. Co. v. U. S. (1912), 226 U. S. 20, 57 L. Ed. 107, 33 Sup. Ct. Rep. 9.

${ }_{26}$ U. S. v. Pacific \& Arctic Rv. \& Nav. Co. (1912), 228 U. S. 87, 57 L. Ed. 742, 33 Sup. Ct. Rep. 433.

27 Addyston Pipe \& Steel Co. v. U. S. (1899), 175 U. S. 211, 44 L. Ed. 136, 20 Sup. Ct. Rep. 96.

28 Montague \& Co. v. Lowry (1904), 193 U. S. 38, 48 L. Ed. 608, 24 Sup. Ct. Rep. 307.

${ }^{29}$ U. S. Trans-Missouri Freight Assn. (1896), 166 U. S. 290, 41 工. Ed. 1007, 17 Sup. Ct. Rep. 540 .

${ }^{30}$ This, it is believed, is the natural deduction from an examination of the opinions of the Supreme Court rendered since the Standard Oil case and dealing with the Sherman act. Indeed, Mr. Justice Day, rendering the opinion in the Union Pacific case, said specifically of the "rule of reason" as applied in the Standard Oil and Tobacco cases: "In those cases it is clearly stated that the decisions in the former cases had been made upon an application of that rule and there was no suggestion that they had not been correctly decided." $226 \mathrm{U}$. S. 61, at p. 284. In the Standard Sanitary case the court treats the Montague decision as still a correct interpretation of the law. $226 \mathrm{U}$. S. 20, at p. 49 . See also the Reading decision, 226 U. S. 324, at p. 370 .

A recent decision of the District Court for the southern District of New York indicates that the judges of that court have doubts as to whether many of the decisions previous to the Standard Oil case are to be treated as the law today.

In U. S. v. Hamburg American S. S. Line et al. (October 13, 1914), 
man act have been dealt with by the courts. One of these cases, United States v. Great Lakes Towing Company, ${ }^{31}$. involved a corporation in many respects more like a railroad company than like an ordinary industrial corporation. Another case concerned the legality of the E. I. Du Pont de Nemours \& Company ${ }^{32}$ and the third was the International Harvester Company case. ${ }^{33}$

On June 2I, I9II, the Circuit Court for the District of Delaware rendered the decision in the Powder Trust case. Circuit Judges Gray, Buffington and Lanning sat in the case. The court held that the E. I. Du Pont de Nemours \& Company, which had gained control of sixty-four to one hundred per cent of the trade of the United States in the different kinds of explosives sold, was a combination in restraint of trade and illegal under the Sherman Act. But the powder company was not a "good trust" and it was manifestly illegal under the principles laid down in the Standard Oil and Tobacco cases. Judge Lanning, rendering the decision of the court, made this declaration of the law applicable to the defendant company:

"It matters not whether the combination be in the form of a trust or otherwise', whether it be in the form of a trada association or a corporation, if it arbitrarily uses its power to force weaker competitors out of business, or to coerce them into a sale to or union with the combination, it puts a restraint upon interstate commerce, and monopolizes or attempts to monopolize a part of that commerce, in a sense that violates the Anti-Trust Act." 34

In February, 19I3, the decision in the case of United States v. Great Lakes Towing Company was handed down. Circuit Judges Warrington, Knappen and Denison of the Sixth Circuit sat in the action. The case involved the legality of a corporation

216 Fed. 971, the court passed upon the validity of an agreement of the North Atlantic Steamship Lines under which rates were fixed and proportionate allotments made in steerage and third class passengers. The court held in a comparatively short opinion that the agreement was a valid one in that it was a reasonable regulation of commerce. Much stress was laid upon a recent report of the Committee on Merchant Marine of the House of Representatives. In this report the agreement was reported reasonable and beneficial in that it eliminated the danger of disastrous rate wars. The court to sustain its opinion merely cites the Standard Oil and Tobacco cases and makes no mention whatsoever of the Trans-Missouri case.

31 (1913), 208 Fed. 733.

32 U. S. v. E. I. Du Pont de Nemours \& Co. (1911), 188 Fed. 127. Fed. 987 .

$33 \mathrm{U}$. S. v. International Harvester Co. (August 12, 1914), 214 34188 Fed. 127, at p. 151. 
which acquired the property and good will of practically all local tug operators in fourteen of the principal lake ports, not including Lake Ontario. It was held that the corporation was in violation of the Sherman Act, for, as the court said:

"It needs no discussion to demonstrate that complete unification of the towing and wrecking facilities at fourteen principal ports, accompanied by restraints with respect to competition imposed on the sellers of towing properties in excess of the legitimate protection necessary to preservation of the business purchased, excessive restrictions against coinpetition under joint operating contracts and on sales of tugs, bitter rate wars, and a system of exclusive contracts with customers such as is found here, all adopted or engaged in for the purpose of effectuating monopolistic control, are abnormal inethods of doing business and eliminating competition, and that a restraint of natural competition by such means is undue restraint." 35

No one can fail to recognize, therefore, the importance of the Harvester case. It is the first decision in which the legality of a large but fair dealing industrial corporation has been tested. This company, because of the extent of its control of the harvester business, has been held to be illegal. If the principles set out in the opinion of the lower court are upheld in the Supreme Court, corporations manufacturing or selling over eighty per cent of the product in their line of business in the United States must prepare to dissolve. And their officers may look forward to criminal actions brought under the Sherman law. This does not mean that the illegal combination need be large from a standpoint of capital. It is the proportionate control of the field of competition that results in the violation of the law.

As pointed out in the Standard Oil case, it was held that the acquisition of a large number of competing plants by a corporation gives rise to a prima facie presumption of intent to dominate the industry through its powers acquired by combination. This prima facie presumption was made conclusive in the Standard Oil, Tobacco, Powder and Towing Company cases cited because of the unfair methods of competition used by those companies. The Harvester Company case in effect holds that if the new corporation is large enough after its acquisition of competing properties, evidence of good conduct does not overcome the presumption of illegality. The corporation is illegal in any event if 
it controls too great a proportion of competitive business. No clues are given in the Harvester case as to how great a proportion of a competitive field of enterprise may be occupied by one corporation. It is true that the court distinguishes large consolidations from small consolidations when it says:

"If the five companies which formed the International had been small, and their combination had been essential to enable them to compete with large corporations in the same line, then their unity would in the light of reason, not have been in restraint of trade, but in the furtherance of it; but when they constituted the largest manufacturers of their articles in America, if not in the world, and held jointly about eighty to eighty-five per cent of the trade, and two at least of the companies forming the combination were prosperous, their combining was, when similarly viewed, an unreasonable restraint of trade."36

But this implied permission can hardly be said to give much light to the industrial world. It recognizes as legal the consolidation of small enterprises under certain circumstances but suggests that even minor competitors cannot combine except when absolutely necessary. In what is perhaps the most striking portion of the court's opinion, it is said:

"We think it may be laid down as a general rule that if companies could not make a legal contract as to prices or as to collateral services they could not legally unite, and as the companies named did in effect unite the sole question is as to whether they would have agreed on prices and what collateral services they should render, when their companies were all prosperous and they jointly controlled eighty to eighty-five per cent of the business in that line in the United States. We think they could not have made such an agreement." 37

Such a test of legality is most discouraging to those who believe in the economies resulting from the doing of business in large units. The natural and great savings resulting from consolidations of industry would seem in such a test to be treated as of no consequence. If three companies can pool their products and agree upon prices they can consolidate, but they cannot do so otherwise. This would seem to be the meaning of the principle as applied. And this test may well threaten the smallest of com-

36 U. S. v. International Harvester Co. (August 12, 1914), 214 Fed. 987, at p. 999.

37 U. S. v. International Harvester Co. (August 12, 1914), 214 Fed. 987, at p. 999. 
binations. The law has been considered settled that agreements between dealers having for their sole purpose the destruction of competition and fixing of prices, are injurious to the public interest and void. ${ }^{38}$ Does the Harvester case result in all combinations being held illegal with the exception mentioned, when the concerns combining are small and combination is a necessity to fight a large corporation? This is a natural question resulting from the decision.

Nearly a quarter of a century has elapsed since the passage of the Sherman Anti-Trust Act. During that time the United States has gained tremendous strength as a power among nations. The same period has seen a world-wide development of consolidation in manufacturing industries because of the recognized economies of production in large units. But in America the Sherman Act, with its sweeping phrases, has threatened the legality of every large consolidation, irrespective of its purpose or effect. Sometimes the act has been construed to one effect and sometimes to another. And the man conceiving and developing any consolidation, no matter how fairly and for how much good to his country, has not known whether or not he was a criminal.

A great war in Europe has increased the relative importance of this country as an exporter of merchandise. Opportunities have arisen to extend the trade of America and to create markets for her products. Yet this year has seen Congress, after a long session, enact a trust program which leaves the Sherman Act as applied to industrial consolidations unchanged. And it has seen a decision rendered by a most able lower court in which the principles laid down menace the very existence of a great part of the large industrial corporations in this country. How can

\$s We have already commented upon the recent decision in the case of U. S. v. Hamburg American S. S. Line (Oct. 13, 1914), 216 Fed. 971, note 30 supra. As stated, the court in its opinion in that case relies solely upon the Standard Oil and Tobacco decisions. It does not treat of the validity of agreements to fix prices. In rendering the opinion of the lower court in the Standard Sanitary case Judge Rose said: "Some men believe that price agreements should be sustained by the courts, unless they are shown to be against the public interest. Others hold that they may be permitted only when it is affirmatively shown that they promote the public interest. Still others say that a price agreement pure and simple is always illegal. That the Supreme Court has declared the last of the above stated contentions to be the law is conclusive here. Only a few months ago it said: "Agreements or combinations between dealers having for their sole purpose the 
America, with her manufacturers thus handicapped, hope to compete with her full strength in the markets of the world?

May we not hope to see legislation which will recognize the desirability and the legality of combinations of industry which are designed, not to further abnormal competition, but to produce cheaply and to sell goods in large quantities on a small margin of profit? If such legislation is not forthcoming, is it too much to desire that the legality of large but fair dealing corporations will be clearly recognized in the courts? Surely we may expect a realization that the men who direct our industries are entitled to know what are and what are not combinations in restraint of trade. For from the business of this country naturally flows the prosperity of its people and, as President Wilson said in his message to Congress relating to Trust legislation, on January 20, I9I4: "Nothing hampers business like uncertainty. Nothing daunts or discourages it like the necessity to take chances, to run the risk of falling under the condemnation of the law before it can make sure just what the law is."

Thomas A. Thacher.

San Francisco, California.

destruction of competition and the fixing of prices are injurious to the public interests and void.' Dr. Miles Medical Co. v. John D. Park \& Sons Co. (1911), 220 U. S. 373, at p. 408, 31 Sup. Ct. Rep. 384, 55 L. Ed. 502." U. S. v. Standard Sanitary Mfg. Co. (1911), 191 Fed. 172 , at p. 182. This decision was handed down in October, 1911, and the court considered the effect of the Standard Oil and Tobacco decisions. The Standard Oil opinion was rendered in May, 1911, and the Dr. Miles Medical Co. case in April, 1911. It seems incredible that the Standard Oil case is to be treated as overthrowing the Dr. Miles Medical Co. case in its doctrine as to the invalidity of price fixing. Until the Supreme Court itself definitely holds that price fixing agreements between sundry independent companies are valid, it is believed that the above statement of the law by Judge Rose is the correct one. 